\title{
INTELLIGENCE AND THE POLITICS OF ZIMBABWE'S PRESIDENTIAL SUCCESSION
}

\author{
BLESSING-MILES TENDI*
}

\begin{abstract}
Since the late 1990s, Zimbabwean politics has been shaped by the political succession war raging within the ruling ZANU PF party. The internal fight to succeed President Robert Mugabe pitted a faction controlled by retired General Solomon Mujuru, who was fronting his wife Joice Mujuru, against another faction led by Emmerson Mnangagwa, a government minister. The competition between these factions reached a crucial stage in 2014, when Mugabe dismissed Joice Mujuru as vice president and purged her key allies in ZANU PF and the government. This article examines the role of state intelligence in this struggle, arguing that the Military Intelligence (MI) leadership, which supported Mnangagwa in the succession war, surveilled Joice Mujuru and constructed a controversial gendered case to destroy her bid to succeed Mugabe. In contrast, some elements in the principal civilian intelligence institution, the Central Intelligence Organization, surveilled the Mnangagwa faction in order to support Joice Mujuru's power bid. Mugabe was persuaded by MI to purge Joice Mujuru because she posed a threat to his hold on power. This course of action was also given some impetus by Mugabe's longstanding grievance against her faction. The article widens scholarship on the security sector's political interventions in Zimbabwean politics, whilst emphasizing how the gendered dimensions of surveillance can reinforce patriarchal national politics.
\end{abstract}

President Robert Mugabe has led the ruling Zimbabwe African National Union Patriotic Front (ZANU PF) party and Zimbabwe since 1977 and 1980, respectively. Mugabe, a nonagenarian, is Africa's oldest serving president. The length of his incumbency among current African leaders is surpassed only by the tenures of Paul Biya (Cameroon), Teodoro Obiang Nguema Mbasogo (Equatorial Guinea) and José Eduardo dos Santos (Angola). Rising domestic discontent with Mugabe's seemingly interminable leadership was one of the reasons for the opposition Movement for Democratic Change (MDC) party's formation in 1999 and the rise to prominence of its leader Morgan Tsvangirai as an alternative national leader. ${ }^{1}$ Indeed, the idiom 'Mugabe must go' was a mantra for the MDC in its formative years. The late 1990s campaign for reform of the national constitution had as one of its leading agendas the adoption of a clause stipulating a two-term limit on the presidency, which would apply retrospectively, thereby barring Mugabe from running for president again. But opposition to Mugabe’s incumbency had even longer lineages within ZANU PF. For instance, from the mid-1980s Edgar Tekere, one of Mugabe's peers in the nationalist struggle for independence, grew increasingly critical of Mugabe's leadership, his plan to establish a one party state, and mounting corruption in government under his watch. ${ }^{2}$ Tekere was eventually expelled from ZANU PF and challenged Mugabe in the 1990 presidential election, which he lost.

Whereas Tekere was ejected from ZANU PF, other critical voices such as Eddison Zvobgo, retired Air Marshal Josiah Tungamirai, Dumiso Dabengwa, retired General Vitalis Zvinavashe, Emmerson Mnangagwa and retired General Solomon Mujuru remained in the party. Mnangagwa

\footnotetext{
* Miles Tendi (miles.tendi@sant.oxon.org) is a Departmental Lecturer in African Politics in the Department of International Development, Queen Elizabeth House, University of Oxford.

${ }^{1}$ Morgan Tsvangirai, Morgan Tsvangirai at the deep end (Eye Books, London, 2011).

${ }^{2}$ Edgar Tekere, A lifetime of struggle (SAPES Books, Harare, 2009).
} 
and General Mujuru, especially, developed a fierce rivalry on the matter of ZANU PF leadership succession from the late 1990s. ${ }^{3}$ Mnangagwa led a faction within ZANU PF and harboured ambition to takeover from Mugabe. Thus, from the late 1990s, Mnangagwa attempted several unsuccessful internal manoeuvres to advance his leadership aspiration. ${ }^{4}$

Although General Mujuru controlled a rival faction, unlike Mnangagwa he did not seek to gain direct control of ZANU PF and the Zimbabwean presidency. General Mujuru considered himself undereducated, hence he preferred to encourage and support highly educated younger party members to aspire to the ZANU PF leadership instead. ${ }^{5}$ After exploring various options to Mugabe, General Mujuru settled for his wife Joice Mujuru (hereafter referred to as Mujuru). ${ }^{6}$ This can be seen in General Mujuru's support for Mujuru's rise to the Zimbabwean vice presidency in 2004, which thwarted a contending bid for the deputy president post by Mnangagwa. However, on 15 August 2011 General Mujuru perished in a suspicious house fire on one of his commercial farms. I have interviewed a range of ZANU PF elites since the fatal fire. A great majority of these elites, many of whom did not belong to the Mujuru faction, believe that General Mujuru's death was a political assassination but there is no consensus on who ordered the elimination.

Still, General Mujuru's demise did not subdue ZANU PF's succession war because Mujuru assumed control of her late husband's faction in 2011 and continued the succession competition with Mnangagwa until December 2014, when Mugabe deposed Mujuru from the party leadership and Zimbabwean vice presidency, and appointed Mnangagwa as her replacement in both posts. In the months prior to Mujuru's political descent, Mugabe wheeled out his wife, the First Lady Grace Mugabe, on a nationwide campaign to denounce Mujuru and to pressure her to resign as vice president. ${ }^{7}$ Grace Mugabe's denunciations of Mujuru were part of an effective, wider and phased systematic purge of the Mujuru faction, first from influential party posts and then positions in government.

Drawing on interviews with senior intelligence operatives, high-ranking military officers and members of the Mujuru and Mnangagwa factions, this article examines the role of intelligence in ZANU PF's 2014 succession politics. ${ }^{8}$ It focuses on intelligence for three reasons. First, anyone who followed events surrounding the 2014 campaign against the Mujuru faction could not fail to notice how central to the purge was the role of state surveillance. The public utterances of Mugabe, Grace Mugabe and Mujuru's other political enemies, as well as the coverage of state television, radio and press, often relied on what was clearly surveillance material gathered by the intelligence sector. Mujuru's political foes claimed to have surveillance data showing that she and her faction

\footnotetext{
${ }^{3}$ Interview, Joice Mujuru, ex-Zimbabwean Vice President, Harare, Zimbabwe, 19 September 2014; Interview, Didymus Mutasa, former ZANU PF Secretary General, Intelligence Minister (2005-2009 and 2013-2014) and Mujuru faction member, Harare, Zimbabwe, 16 September 2014.

${ }^{4}$ For accounts of Mnangagwa's succession schemes, see Blessing-Miles Tendi, 'Ideology, civilian authority and the Zimbabwean military', Journal of Southern African Studies 39, 4 (2013), pp. 829-843; Ibbo Mandaza, 'ZANU PF congress - the rise and triumph of the securocratic state', 15 December 2014, Zimbabwe Independent,

<http://www.theindependent.co.zw/2014/12/15/zanu-pf-congress-rise-triumph-securocratic-state/> (16 April 2015).

${ }^{5}$ Interview, Joice Mujuru, Harare, Zimbabwe, 19 September 2014; Interview, Didymus Mutasa, Harare, Zimbabwe, 16 September 2014; Interview, Rugare Gumbo, ex-ZANU PF spokesperson and Mujuru faction member, Harare, Zimbabwe, 3 January 2015.

${ }^{6}$ Interview, Joice Mujuru, Harare, Zimbabwe, 19 September 2014.

${ }^{7}$ Interview, Key planner A in anti-Mujuru campaign, Harare, Zimbabwe, 15 December 2014; Interview, Key planner B in anti-Mujuru campaign, Harare, Zimbabwe, 8 January 2015.

${ }^{8}$ Intelligence is murky and complex, and research in this field is difficult. I have established relationships with my interviewees over repeated interviews since 2010. I also sought to corroborate views, as far as is possible.
} 
furtively plotted to assassinate Mugabe. ${ }^{9}$ According to Mugabe, one of these murder schemes involved a semi-naked Mujuru casting deathly witchcraft hexes on him. ${ }^{10}$ Second, Zimbabwe's security institutions are highly politicized, with little distinction between the ruling party and state, ${ }^{11}$ and thus it is important to account for their role in explaining the course of ZANU PF's factional wars. Third, the leading protagonists in the succession battles, General Mujuru, Mnangagwa and Mujuru, have extensive links to the security sector. In the 1970s, General Mujuru was the Chief of Operations in the Zimbabwe African National Liberation Army (ZANLA), which was ZANU PF's military wing during the liberation war. General Mujuru became the commander of the Zimbabwe National Army, post-independence. He retired from the army in 1992 but retained considerable influence in the security sector, which he often leveraged in support of his political goals in ZANU PF. Mnangagwa was among the first group of ZANLA fighters sent to China for military training in 1963, although he never saw active combat. ${ }^{12}$ In independent Zimbabwe, Mnangagwa held security portfolios such as the Ministries of Intelligence and Defence. In Mujuru's case, in the 1970s she was the head of the ZANLA women's detachment and held the Ministry of Defence portfolio at one point during the independence period.

The article argues that under a façade of inflexible loyalty to Mugabe, a section of the Military Intelligence (MI) leadership, which backed Mnangagwa in the succession infighting, surveilled Mujuru and assembled a controversial, gendered case to obliterate her ambition to become president. In opposition to MI, some actors in the leadership of the primary intelligence institution, the Central Intelligence Organization (CIO), which is manned by civilians, compiled dossiers against the Mnangagwa faction so as to bolster Mujuru's quest to succeed Mugabe. The CIO and MI leaderships presented their separate and contrasting politicized intelligence to Mugabe, each with the intention of influencing him to act against the faction they opposed. However, neither group was homogenous in its views. For example, some CIO intelligence operatives passed information exposing their superiors' biased intelligence work to Mugabe via officials in his inner circle. These CIO intelligence leaks must be seen against a background of historical internal divisions in the organization. In the end, Mugabe was influenced by MI's surveillance material and purged the Mujuru faction from senior party and government posts because it was a more significant challenge to his hold on power than the Mnangagwa group, ahead of ZANU PF's December 2014 elective congress at which, according to MI, Mujuru planned to challenge Mugabe for the party leadership. While MI was central to Mugabe’s decision to expunge the Mujuru group from leadership positions, his resolution was also given some stimulus by the fact that he blamed General Mujuru for his defeat in the March 2008 presidential election. Following Mugabe's refusal to step aside for a different ZANU PF candidate in the 2008 presidential election, General Mujuru sponsored a younger party member to challenge Mugabe as an independent competitor in the poll. General Mujuru's maneuver divided ZANU PF and Mugabe

\footnotetext{
${ }^{9}$ Sunday Mail, 'VP Mujuru linked to president assassination plot', 16 November 2014, $<$ http://www.sundaymail.co.zw/?p=19585> (16 April 2015).

${ }^{10}$ Bulawayo 24, 'Bare breasted Mujuru wanted to kill me', 28 February 2015, <http://www.bulawayo24.com/indexid-news-sc-national-byo-63559.html> (16 April 2015).

${ }^{11}$ Knox Chitiyo, 'The case for security sector reform in Zimbabwe', Royal United Services Institute, September 2009, <www.rusi.org/downloads/assets/Zimbabwe_SSR_Report.pdf> (16 April 2015).

12 Interview, Emmerson Mnangagwa, Harare, Zimbabwe, 24 August 2011; Paul Moorcraft and Peter McLaughlin, The Rhodesian war: a military history (Stackpole, Mechanicsburg, 2013).
} 
saw this division as having caused his defeat. ${ }^{13}$

The next section situates the article within the existing literature on intelligence and politics. The second part explains historical divisions within the CIO and the subsequent split between MI and $\mathrm{CIO}$, while the third part demonstrates the gendered nature of the surveillance material deployed against Mujuru and unpacks the assassination accusations against the Mujuru faction. The article concludes by explaining why Mugabe was persuaded by MI's surveillance data and ousted the Mujuru group from leadership positions.

\section{Perspectives on intelligence and politics}

The scholar JoAnn McGregor has highlighted the importance of CIO surveillance practices in the disciplining and control of Zimbabwe's urban local government officials during the country's power-sharing period from 2009 to $2013 .{ }^{14}$ These state surveillance activities were part of an eclectic ZANU PF strategy to regain control of urban local government structures, following dismal electoral losses in preceding years. CIO’s surveillance reach and, more generally, the preponderance of the Zimbabwean state are justifiably seen as institutional legacies of the colonial Rhodesian state, which was strong, highly bureaucratized and centralized. ${ }^{15}$

Other literatures about surveillance and politics in Africa by Andrea Purdekova and David Bozzini illustrate how legacies of violent conflict undergird strong surveillance institutions and practices in Rwanda and Eritrea, respectively. ${ }^{16}$ Purdekova and Bozzini argue that the strength of Rwandan and Eritrean state surveillance facilitates the reproduction of myriad insecurities, suspicions and fears among surveillance subjects, ${ }^{17}$ which is a pattern McGregor also identifies in her work on the role of CIO surveillance in Zimbabwe. ${ }^{18}$ South Africa's intelligence services have attracted some of the most concentrated scholarly attention on the continent, both during the apartheid and democratic periods. ${ }^{19}$ Martin Plaut and Paul Holden accord a degree of importance to surveillance activities by South Africa's National Intelligence Agency in influencing domestic politics. ${ }^{20}$ Jane Duncan, however, takes a different view to that of Plaut and Holden by arguing that in actual fact 'securocrats' (intelligence operatives wielding political influence) have acquired authority over President Jacob Zuma’s ANC government. ${ }^{21}$ Collectively, such work on the

\footnotetext{
${ }^{13}$ Interview, Key planner A in anti-Mujuru campaign, Harare, Zimbabwe, 15 December 2014; Blessing-Miles Tendi, ‘Robert Mugabe's 2013 presidential election campaign', Journal of Southern African Studies 39, 4 (2013), pp. 963-970.

${ }^{14}$ JoAnn McGregor, 'Surveillance and the city: patronage, power-sharing and the politics of urban control in Zimbabwe', Journal of Southern African Studies 39, 4 (2013), pp. 783-805.

15 Jocelyn Alexander and JoAnn McGregor, 'Introduction: politics, patronage and violence in Zimbabwe', Journal of Southern African Studies 39, 4 (2013), pp. 749-763.

${ }^{16}$ Andrea Purdekova “"Even if I am not here, there are so many eyes”: surveillance and state reach in Rwanda', Journal of Modern African Studies 49, 3 (2011), pp. 475-497; David Bozzini, 'Low-tech surveillance and the despotic state in Eritrea’, Surveillance and Society 9, 1/2 (2011), pp. 93-113.

${ }^{17}$ Ibid.

${ }^{18}$ McGregor, 'Surveillance and the city'.

${ }^{19}$ Some classic works include: Stephen Ellis, 'Mbokodo: security in ANC camps, 1961-1990', African Affairs 93, 371 (1994), pp. 279-298; Tom Lodge, 'State of exile: the African National Congress of South Africa, 1976-1986', Third World Quarterly 9, 1 (1987), pp. 1-27.

${ }^{20}$ Martin Plaut and Paul Holden, Who rules South Africa? (Jonathan Ball, Johannesburg, 2012).

${ }^{21}$ Jane Duncan, The rise of securocrats: the case of South Africa (Jacana, Johannesburg, 2014).
} 
effective surveillance practices of strong capable states helps highlight the tendency to overemphasize state 'weakness' or 'failure' in Africa. ${ }^{22}$

This article makes a contribution by illuminating how the gendered nature of surveillance practices reinforces patriarchal national politics. The security sector is imbued with gendered and patriarchal values and discourses. ${ }^{23}$ These prevalent norms and discourses result in a gendered intelligence field. Finnish social geographer Hille Koskela, for instance, alerts us to the fact that everyday surveillance through cameras in public spaces reproduces gendered scrutiny. ${ }^{24}$ 'Seeing and being seen are gendered' and voyeurism often accompanies gendered seeing behind surveillance cameras - a phenomenon Koskela refers to as 'peeping Tom goes high tech'. ${ }^{25}$ For these reasons MI officers who surveilled Mujuru gathered gendered surveillance material. As this article illustrates, the kind of surveillance material gathered by MI about Mujuru partly drew on what her detractors claimed was authentic surveillance footage of her without clothes, performing witchcraft acts aimed at killing Mugabe so that she could take over the presidency sooner rather than later. Accusations of witchcraft are highly gendered. ${ }^{26}$ Accusing Mujuru of witchcraft was also an attempt to legitimize her expulsion from the ZANU PF leadership, and it made her open to rhetorical and physical attacks. As can be seen in the work of Timothy Scarnecchia, political witch-hunts have long established roots in ZANU PF. ${ }^{27}$ The historian Gerald Mazarire has also written about how civilians and guerrillas in ZANLA camps lived under close surveillance and fear of the guerrilla army's security department. ${ }^{28}$ Mazarire demonstrates how this security division often summarily targeted perceived sell-outs and conducted witch-hunts, using violence, torture and public humiliation during parades in ZANLA camps.

This article also draws a distinction between military and civilian intelligence institutions, which refines Ibbo Mandaza's analysis of the 2014 political upheavals in ZANU PF. Mandaza presents the liquidation of the Mujuru faction as marking the ascent and 'triumph' of an integrated 'securocratic state', ${ }^{29}$ but as shown here, this 'securocratic state' was hardly unified. It is therefore more precise to write of a triumph of the military intelligence section of a 'securocratic state'. The scholar John Hughes Wilson contends that the distinction between military and civilian intelligence is misleading because 'all intelligence is government intelligence; it tends to become a military [intelligence] problem only when it [security/events] goes horribly wrong’ ${ }^{30}$ However,

\footnotetext{
22 Examples in this weak state literature are: Robert Rotberg (ed.), When states fail: causes and consequences (Princeton University Press, New Jersey, 2003); Robert Jackson and Carl Rosberg, 'Why Africa's weak states persist', World Politics 35, 1 (1982), pp. 1-24; William Reno, 'Congo: from state collapse to “absolutism”, to state failure', Third World Quarterly 27, 1 (2006), pp. 43-56; William Zartmann, Collapsed states: the disintegration and restoration of legitimate authority (Lynne Reinner, Boulder, 1995).

${ }^{23}$ Rahel Kunz, 'Gender and security sector reform: gendering differently?', International Peacekeeping 21, 5 (2014), pp. 604-622.

${ }^{24}$ Hille Koskela, 'Video surveillance, gender and the safety of public urban space: “peeping Tom” goes high tech?', Urban Geography 23, 3 (2002), pp. 257-278.

25 Ibid.

${ }^{26}$ Tabona Shoko, Karanga indigenous religion in Zimbabwe: health and well-being (Ashgate, Burlington,

2013); Jean Comaroff and John Comaroff (eds), Modernity and its malcontents: ritual and power in postcolonial Africa (Chicago University Press, Chicago, 1993).

27 Timothy Scarnecchia, The urban roots of democracy and political violence in Zimbabwe, Harare and Highfield, 1940-1964 (Rochester University Press, Rochester, 2008).

${ }^{28}$ Gerald Mazarire, 'Discipline and punishment in ZANLA: 1964-1979', Journal of Southern African Studies 37, 3 (2011), pp. 571-591.

${ }^{29}$ Mandaza, 'ZANU PF congress - the rise and triumph of the securocratic state'.

${ }^{30}$ John Hughes Wilson, Military intelligence blunders and cover-ups (Robinson, London, 2004), p. vii.
} 
as this article will demonstrate, there is a real distinction between civilian and military intelligence, and the division is deepened in contexts of militarization (the appointment of military officers to the leadership of civilian intelligence institutions), politicization of security institutions and an acutely factionalized ruling party.

\section{Intelligence failures: politicization, division and conspiracy}

The CIO has a long history of politicization, internal division and distrust in its uppermost stratum. CIO is an intelligence vestige of the colonial Rhodesian state. It was formed in 1963 and had Ken Flower as its founding Director General while the Director Internal (responsible for domestic intelligence gathering) was Derrick Robinson. ${ }^{31}$ Flower's institutional design of CIO was such that 'CIO, and only CIO, should coordinate all intelligence acquired from internal, external and liaison sources', which meant that MI was merely a division within CIO responsible for amassing intelligence in the military and whose director reported to the Director General. ${ }^{32}$ From its inception CIO was highly politicized because one of its functions was to act as a political instrument in the colonial state's resistance against pressure for black majority rule. According to Dan Stannard, a state intelligence operative during the colonial years, and the former Rhodesian army commander General Sandy Maclean, Robinson and Flower were persistently accompanied by allegations within the security sector that they were double agents. Flower particularly, Stannard and Maclean recounted, was suspected of being loyal to Britain's Secret Intelligence Service (MI6), although this suspicion was never supported by concrete evidence at the time. ${ }^{33}$ Stannard recalled that:

If we had a meeting and there was an important decision to be made about our intelligence, Flower
prevaricated. Soon after he would travel to London and upon his return he would take a decision.
Prevarication, a trip abroad, swift decision when home. This tended to be his pattern on major issues.
We were suspicious of him and that divided the organisation. In my case, what confirmed my suspicions
about him was his conduct in the 1980 [independence] election. CIO had worked on a plan to rig the
election for [Abel] Muzorewa. We had boxes and boxes of stuffed ballots. We worked out how to enter
undetected where the cast ballots were stored and we were going to replace them with CIO ballot boxes.
I was deployed to Bindura for this operation. Flower stalled on giving the order to start rigging, then he
just called it off. I was surprised because the plan was agreed. To me this meant he was not his own man.

Former British Foreign Secretary (1977-79) Lord David Owen validated Stannard's claims about Flower by stating that 'Flower was on our [Britain's] side. So I was well aware of what Ken Flower was claiming was being done [by the Rhodesian Security Forces], and I used to read the

\footnotetext{
${ }^{31}$ Ken Flower, Serving secretly. An intelligence chief on record: Rhodesia into Zimbabwe, 1964 to 1981 (John Murray, London, 1987).

32 Ibid., p. 17.

${ }^{33}$ Interview, Dan Stannard, Newmarket, England, 23 June 2014; Interview, General Sandy Maclean, Harare, Zimbabwe, 23 August 2014.

${ }^{34}$ Interview, Dan Stannard, Newmarket, England, 23 June 2014. Muzorewa was Prime Minister (June-December 1979) of Zimbabwe-Rhodesia after the 1978 Internal Settlement, which gave 'moderate' blacks a place in government. Whites retained authority in the arrangement and they supported Muzorewa's candidature in the 1980 election.
} 


\section{[CIO] reports'. ${ }^{35}$}

Evidently, CIO’s institutional history during the colonial years is partly defined by politicisation and internal suspicion and division over its leadership's allegiances. Apprehension and disunion over the CIO directorship's integrity continued in the independence period but a new variety of politicization emerged. Continuity of distrust and disunity from the colonial years has, to a degree, its source in the independence (1980) government's retention of Flower as the Director General of CIO, along with other willing former Rhodesian intelligence operatives such as Stannard who continued to view Flower negatively. ${ }^{36}$ According to Flower, Emmerson Mnangagwa (Intelligence minister, 1980-88) 'asked me to stay in office for at least the two-year period it would take to reconstruct CIO, I agreed but maintained there was little need for change, particularly if they wished the organization to retain its professional standards'. ${ }^{37}$ Flower adds that Mnangagwa acquiesced to his standpoint against post-independence reconstruction and 'left the professional control of CIO to me, while he provided the political link to government'. ${ }^{38}$ According to Mnangagwa, 'we [ZANU PF] really wanted our institutions to work but we were careful about the whites [who remained in CIO]. We could never fully trust some of them'. ${ }^{39}$

Still, CIO did undergo Africanization from 1980. It became a mixture of past Rhodesian intelligence operatives, former ZANLA members and a minority of ex-Zimbabwe People's Revolutionary Army (ZIPRA) elements. ${ }^{40}$ There is a dearth of meticulous accounts on the configuration of the National Security Organization, ZIPRA's intelligence arm during the liberation war, as well as on its relationship with military intelligence. ${ }^{41}$ There are, however, some pertinent analyses on ZANLA intelligence, which was subsumed in its security department. ${ }^{42}$ Fay Chung writes that the security department played 'the dual role of providing "protection" while at the same time spying on the person who was being protected'. ${ }^{43}$ Chung concludes that this dual practice endured in the independence period because of the integration of the ZANLA security department into CIO from 1980. Certainly, my ZANU PF interviewees viewed CIO's double utility as partly a legacy of the ZANLA security department's dual role during the liberation war. ${ }^{44}$ ZANLA and ZIPRA were acrimonious rivals throughout the war. This old ZIPRA-ZANLA rivalry created a new split and climate of mistrust in CIO. As early as 1981 ZANU PF began accusing ZAPU of using former ZIPRA soldiers to foment dissident activity in the south of Zimbabwe. Consequently, from 1981, Stannard maintained, the minority former ZIPRA elements

\footnotetext{
${ }^{35}$ Lord David Owen interview (with Mike Thomson), 'Document', BBC Radio 4, 1 August 2011, <http://www.bbc.co.uk/programmes/b012wf3s> (16 April 2015).

${ }^{36}$ Interview, Dan Stannard, Newmarket, England, 23 June 2014.

${ }^{37}$ Flower, Serving secretly, p. 272.

38 Ibid..

${ }^{39}$ Interview, Emmerson Mnangagwa, Harare, Zimbabwe, 24 August 2011.

${ }^{40}$ Ibid. ZIPRA was ZAPU's military arm.

${ }^{41}$ Illustrations of this lack of meticulous attention to ZIPRA intelligence structures include: Dumiso Dabengwa, 'ZIPRA in the Zimbabwe war of national liberation' and Jeremy Brickhill, 'Daring to storm the heavens: the military strategy of ZAPU, 1976-79’, in Ngwabi Bhebe and Terence Ranger (eds), Soldiers in Zimbabwe’s liberation war (James Currey, London, 1995).

${ }^{42}$ Examples are: Mazarire, 'Discipline and punishment in ZANLA'; Fay Chung, Re-living the second chimurenga. Memories from Zimbabwe's liberation struggle (Weaver Press, Harare, 2007).

${ }^{43}$ Chung, Re-living the second chimurenga. p. 132.

${ }^{44}$ Interview, Joice Mujuru, Beatrice, Zimbabwe, 4 January 2015; Interview, Rugare Gumbo, Harare, Zimbabwe, 3 January 2015; Interviewee B, former ZANLA guerrilla and high-ranking member of security establishment, Harare, Zimbabwe, 11 December 2014; Interviewee C, former ZANLA guerrilla and high-ranking member of security establishment, Harare, Zimbabwe, 17 December 2014.
} 
were 'weeded out from CIO in a very systematic way because they were passing intelligence to Dumiso Dabengwa [ex-ZIPRA intelligence chief] and Swazini Ndlovu who was Dabengwa's number two'. ${ }^{45}$ By 1987, when the ZANU PF and ZAPU hostilities were resolved through the signing of a unity accord that subordinated the latter to the former, CIO was now ex-ZANLA dominated - an outcome that underscored a new form of politicization in CIO. ${ }^{46}$ The number of ex-Rhodesian operatives had also dwindled by 1987, with the retirement of the divisive Flower being the most significant single departure. Stannard observed that CIO became a 'more or less settled' organization in terms of ex-ZANLA supremacy from 1987 onwards. ${ }^{47}$ However, he identified a meaningful development in the mid-1990s, which was that:

\begin{abstract}
CIO little by little stopped doing hard intelligence work because we now had corrupt, feuding Directors. The Director General at the time was called Shadreck Chipanga and the Deputy Director General was Lovemore Mukandi. Shadreck and Lovemore were fighting each other for control of CIO. It divided CIO right down the middle. I remember seeing the whole fibre of CIO change. Standards fell. The quality of intelligence reports to me was going down but Shadreck and Lovemore did not seem to care. CIO became more and more about making money for the chefes. Lovemore more than Shadreck was a fiddler who was formerly Director Administration in CIO. Also part of the problems was that they were not renewing the organisation enough. There were too many ZANLA types who had been in CIO since 1980 who started to see being in $\mathrm{CIO}$ as a right when what they were there for was hard intelligence work. ${ }^{48}$
\end{abstract}

An ex-intelligence minister responded to Stannard's observation by saying: 'these [white] Rhodesians always say that things worked better during colonialism but this time they are correct. CIO got worse under us [ZANU PF]'. ${ }^{49}$ The former intelligence minister Didymus Mutasa also observed that CIO produced 'not very good reports really. I had to read them. They made me tired'. ${ }^{50}$

In response to the escalating 1990s institutional malaise, Mugabe summarily dismissed Chipanga and Mukandi in 1998, a move that resulted in the latter fleeing to Canada to avoid prosecution for fraud in CIO. ${ }^{51}$ Mugabe militarized the CIO leadership by replacing Mukandi and Chipanga with two brigadiers, Elisha Muzonzini and Happyton Bonyongwe. A former intelligence minister alleged that General Mujuru and Mugabe still had a functional political relationship at the time and hence the general successfully recommended Muzonzini and Bonyongwe to Mugabe. ${ }^{52}$ Muzonzini was appointed Director General and Bonyongwe became the new Deputy Director General. Stannard maintained that 'Mugabe needed to get order back in CIO so that is why he turned to the military'. ${ }^{53}$ In addition, Muzonzini and Bonyongwe were outsiders to the ChipangaMukandi power struggle, making it plausible that Mugabe saw the imposition of an external

\footnotetext{
45 Interview, Dan Stannard, Newmarket, England, 23 June 2014.

46 Interview, Dan Stannard, Newmarket, England, 23 June 2014; Interview, Intelligence Operative A, Harare, Zimbabwe, 3 January 2014; Interview, Intelligence Operative B, Harare, Zimbabwe, 24 December 2014.

${ }^{47}$ Interview, Dan Stannard, Newmarket, England, 23 June 2014.

${ }^{48} \mathrm{Ibid}$. ZANU PF elites are commonly referred to as chefes, which is a Portuguese word meaning bosses. ZANU

$\mathrm{PF}$ appropriated the term during its time in Portuguese speaking Mozambique, where it had guerrilla bases for part of the liberation war.

${ }^{49}$ Interview, Former Intelligence Minister A, Harare, Zimbabwe, 7 September 2015.

${ }^{50}$ Newsday, 'I am ready for jail: Mutasa', 1 July 2015, <https://www.newsday.co.zw/2015/07/01/i-am-ready-forjail-mutasa/> (23 October 2015).

${ }^{51}$ Interview, Dan Stannard, Newmarket, England, 23 June 2014.

${ }^{52}$ Interview, Former Intelligence Minister A, Harare, Zimbabwe, 7 September 2015.

${ }^{53}$ Interview, Dan Stannard, Newmarket, England, 23 June 2014.
} 
leadership as a way of subduing Mukandi and Chipanga's respective factions in CIO.

Whatever the merits of Mugabe's decision to militarize the CIO leadership, his determination spawned new fault lines and mistrust in the organization. Mugabe removed Muzonzini from the Director General post in 2003 because he presented critical intelligence reports to him before the 2000 parliamentary and 2002 presidential elections that pointed to Mugabe's declining electoral appeal. ${ }^{54}$ Bonyongwe succeeded Muzonzini but he too did not have Mugabe's complete trust because:
Mugabe suspected that [General] Mujuru had instructed Muzonzini to produce reports to convince him to step down [from power] and because Bonyongwe had come [to CIO] with Muzonzini on [General] Mujuru's advice, Mugabe was suspicious of Bonyongwe. ....Mugabe said to me, 'Bonyongwe is [General] Mujuru's man. I want to know what [General] Mujuru is doing [in ZANU PF] so create a parallel intelligence structure for spying on [General] Mujuru and bring that information directly to me'. Every time I met Mugabe alone, he always asked what [General] Mujuru was doing. He was very worried that [General] Mujuru would remove him from power. ${ }^{55}$

Bonyongwe has held the Director General post since 2003, meaning that military officers have led CIO for approximately two decades now. Yet CIO is a civilian institution manned by career intelligence officers. The imposition of military officers without a civilian intelligence background irked ambitious long serving civilian intelligence operatives in CIO who had been waiting their turn to succeed Chipanga and Mukandi. ${ }^{56}$

An additional schism engendered by Mugabe's militarization of the CIO directorship centred on the divergent institutional cultures between intelligence and the military. Intelligence data may help inform the military's tactical manoeuvres in warfare but intelligence work and soldiering remain disparate practices. Contrasting practices dictate dissimilar institutional cultures and leadership styles. ${ }^{57}$ The core business of the military is warfare. The quintessence of military leadership is command and control, hence the military's institutional culture is ineludibly topdown or hierarchical, emphasizing discipline, procedure and unquestioning allegiance to the command. On the other hand, the intelligence realm is about the acquirement, scrutiny, debate and control of information. Accordingly the culture of intelligence institutions values the contestation of information and critical analyses over complete subservience to the command and its orders. ${ }^{58}$ Given these important differences, the military leaders in CIO did not always find it easy to abandon the armed force's top-down culture, as seen in the following criticism of Bonyongwe's conduct during meetings: 'he has a habit of interrupting others during briefing sessions. Bonyongwe likes to overrule other people's views by simply saying that is wrong. He rarely bothers to offer an alternative viewpoint'. ${ }^{59}$ In addition, Mutasa recalled an occasion in 2014 in which he attempted to mediate a dispute between Bonyongwe and a high ranking civilian intelligence operative, by stating: 'Bonyongwe flatly refused to talk. He said this person is a

\footnotetext{
${ }^{54}$ Interview, Former Intelligence Minister A, Harare, Zimbabwe, 7 September 2015.

55 Ibid.

${ }^{56}$ Interview, Intelligence Operative A, Harare, Zimbabwe, 3 January 2014; Interview, Intelligence Operative B, Harare, Zimbabwe, 24 December 2014.

${ }^{57}$ Samuel Huntington, The soldier and the state: the theory and politics of civil-military relations (Harvard University Press, Cambridge: MA, 1981).

${ }^{58}$ Amy Zegart, 'King David. Why generals should not run the CIA', Foreign Policy (November 2012).

${ }^{59}$ Interview, Key planner A in anti-Mujuru campaign, Harare, Zimbabwe, 15 December 2014.
} 
subordinate. I cannot sit down to discuss with a subordinate'. ${ }^{60}$

In opposition to the aforementioned criticisms made by civilians, Bonyongwe's former Zimbabwean military peers and British Military Advisory and Training Team officers, who helped train and integrate the Zimbabwe National Army from 1980 to 2001, regarded him as a first-class soldier who harboured a reasonable ambition to become the Zimbabwe Defence Forces commander. ${ }^{61}$ Bonyongwe received part of his officer training in well-regarded British military academies and at the time of his reassignment to CIO as Deputy Director General, he was the Commandant of the esteemed Zimbabwe Staff College. ${ }^{62}$ Nonetheless, Bonyongwe's recognised talents in the military did not shield him from having his authority questioned in CIO. What is more, the contentiousness of Bonyongwe's directorship was heightened by his alleged allegiance to General Mujuru’s faction in ZANU PF’s succession war:

\begin{abstract}
When General Mujuru was still in the army one of his blue-eyed boys was Bonyongwe. That was their connection. There was a build-up of intelligence reports from below in CIO implicating General Mujuru in plots to end the president's leadership. As DG, Bonyongwe suppressed these reports. Bonyongwe's subordinates in CIO were unhappy with this so they started approaching people close to the president for this information to reach the president's desk. These same subordinates warned people who were being bugged by Bonyongwe to be careful what they said on their phones. ${ }^{63}$
\end{abstract}

Bonyongwe's directorship was further beleaguered during the 2008 election. Subsequent to his failure to prevent Mugabe from standing as ZANU PF's candidate in the March 2008 presidential election, General Mujuru was purported to have helped sponsor a younger and well educated ZANU PF politician - the former Finance Minister Dr Simbarashe Makoni - to challenge Mugabe in the poll as an independent candidate. ${ }^{64}$ Makoni cast himself as a 'route to ZANU PF renewal in a version acceptable to the West and to Zimbabwe's powerful South African neighbour. Makoni carefully positioned himself as a reformer who would revive not destroy ZANU PF and as a technocrat who could fix the economy, something Mugabe... patently could not' ${ }^{65}$ According to a member of General Mujuru's faction:

\footnotetext{
The Makoni issue was being done at the general's office. I saw it. [Dumiso] Dabengwa would come there for meetings with the general on the Makoni issue. The general was involved. The general was saying to MPs, 'contest as ZANU PF because ZANU PF does not belong to Mugabe. Makoni will contest as an independent and win and come back to work with ZANU PF MPs'. That is what the general said to me. But eventually the general saw that Makoni did not have the strong support he initially thought he had, so he never came out to publicly support Makoni. ${ }^{66}$
}

\footnotetext{
${ }^{60}$ Interview, Didymus Mutasa, Harare, Zimbabwe, 10 September 2015.

${ }^{61}$ Interview, ex-BMATT Commander, London, England, 23 July 2011; Interview, Military Officer A, Harare, Zimbabwe, 17 December 2014; Interview, Military Officer B, Harare, Zimbabwe, 23 December 2014.

62 Ibid.

${ }^{63}$ Interview, Key planner A in anti-Mujuru campaign, Harare, Zimbabwe, 15 December 2014.

${ }^{64}$ Jocelyn Alexander and Blessing-Miles Tendi, 'A tale of two elections: Zimbabwe at the polls in 2008', ACAS Bulletin 80 (2008), pp. 5-17.

${ }^{65}$ Ibid.

${ }^{66}$ Interview, Mujuru Faction Member A, Harare, Zimbabwe, 7 January 2015.
} 
Dabengwa, who left ZANU PF to support Makoni in the 2008 election, confirmed to me in an interview that General Mujuru had in fact supported Makoni's candidature. ${ }^{67}$ Pertinently, Bonyongwe was accused of complicity in 'the Makoni issue' ${ }^{68}$ However, given the number of Bonyongwe's critics, it is also plausible that 'the Makoni issue' was instrumentalized by his opponents in an attempt to bring down his directorship.

The Makoni issue had a detrimental effect on Mugabe's campaign. Makoni's surprise candidature caused widespread division, confusion and distraction in Mugabe's traditional strongholds of support. ${ }^{69}$ Tsvangirai won the March presidential election with 47 percent of the votes, Mugabe secured 43 percent and Makoni came third with 8 percent. But the result took over a month to release, casting some doubt on whether this official count was a true reflection of the poll outcome. Certainly, many ZANU PF politicians have in private admitted to me that they believe Mugabe lost to Tsvangirai by a wider margin. The official result guaranteed Mugabe another run for the presidency in a June runoff election with Tsvangirai who had failed to secure the necessary 51 percent to win the March election outright. Mugabe won the June runoff, relying mainly on a nationwide campaign of violence, intimidation and the displacement of opposition supporters, which forced Tsvangirai to withdraw his candidature.

After regional mediation led by South African President Thabo Mbeki, Mugabe entered a power-sharing government with Tsvangirai as a means of addressing his re-election's lack of legitimacy. Mugabe was deeply wounded by his March 2008 loss and being forced to share power with Tsvangirai, as well as by the fact that some ZANU PF members had undermined his campaign. ${ }^{70}$ But it is imperative to place Mugabe's defeat within a context of cataclysmic economic decline and the breakdown of social services in 2008, which was an additional determining factor in his election defeat. ${ }^{71}$

Subsequent to his March 2008 loss, Mugabe did not immediately begin a programme of internal retribution targeting the Mujuru faction. For Bonyongwe, his alleged connivance in 'the Makoni issue' meant that although he retained the Director General post in CIO, he was now perceived as a severely compromised intelligence chief. Amid the suspicions, Mugabe took a more secretive approach to the management of his campaign preparations for the 2013 presidential election - a poll Mugabe won with 61 percent of the votes. ${ }^{72}$ Mugabe made use of figures such as Mnangagwa, the war veterans (of the 1970s liberation war) leader Jabulani Sibanda, the Zimbabwe Defence Forces commander Constantine Chiwenga and mandarins in the president's office he considered loyal to operationalize his 2013 campaign strategy. ${ }^{73}$ Mugabe had deployed many of these same actors to mount his fight-back in the June 2008 runoff election.

\footnotetext{
${ }^{67}$ Interview, Dumiso Dabengwa, Bulawayo, Zimbabwe, 4 January 2012.

${ }^{68}$ Interview, Intelligence Operative A, Harare, Zimbabwe, 3 January 2014; Interview, Key planner A in antiMujuru campaign, Harare, Zimbabwe, 15 December 2014.

69 Alexander and Tendi, 'A tale of two elections'.

70 Tendi, 'Robert Mugabe’s 2013 presidential election campaign’; Eldred Masunungure (ed), Defying the winds of change. Zimbabwe’s 2008 elections (Weaver Press, Harare, 2009).

${ }^{71}$ For an insightful analysis of the scope of the problems, the reorientation of economic activity and the metaphorics of everyday existence at the time, see Jeremy Jones, “Nothing is straight in Zimbabwe”: the rise of the kukiya-kiya economy 2000-2008', Journal of Southern African Studies 36, 2 (2010), pp. 285-299.

72 Tendi, ‘Robert Mugabe’s 2013 presidential election campaign'.

${ }^{73}$ Interview, Key planner A in anti-Mujuru campaign, Harare, Zimbabwe, 15 December 2014; Interview, Intelligence Operative A, Harare, Zimbabwe, 3 January 2014; Interview, Military Officer A, Harare, Zimbabwe, 17 December 2014; Interview, Military Officer B, Harare, Zimbabwe, 23 December 2014.
} 
Tellingly, perceived members of the Mujuru faction were not privy to some of the core aspects of the 2013 presidential election strategy. Mujuru, who was vice president at the time, commented that 'he [Mugabe] deliberately excluded me from things about the [2013] election. One example is money for the election. Our accounts showed we did not have the money for the election so I would ask him many times where we were going to get the money for the election. His answers were never clear and then the money was suddenly found and he never told me where he got it'. ${ }^{74}$ A figure who was part of Mugabe's exclusive campaign team related that: 'we flew in [from China via the Democratic Republic of Congo] bulks and bulks of election campaign material on an... aircraft at night and stored the material in State House [official presidential residence] without the man in charge of red bricks knowing it'. ${ }^{75}$

The CIO leadership's marginalisation from some of the core presidential election planning opened up space for the rise of MI, which was controlled by Chiwenga. However, Chiwenga was not an impartial bystander in ZANU PF's succession war. As one senior military officer asserted, 'Chiwenga's plan is to succeed ED [Mnangagwa] after ED succeeds Mugabe. When ED is president, Chiwenga will be his vice president. There is an alliance between the two'. ${ }^{76}$ Chiwenga also supported Mnangagwa for the reason that General Mujuru opposed his bid to become Zimbabwe Defence Forces commander in 2003, and because both military officers had a history of intense personal rancour. ${ }^{77}$

I have written elsewhere that an extensive network of retired military officers helped mobilize support for Mugabe in the 2013 election. ${ }^{78}$ These officers, many of whom were ex-ZANLA and retired from the military specifically for the 2013 campaign, were deployed in the Zimbabwean countryside as Political Commissars. ${ }^{79}$ The use of retired soldiers as Political Commissars was a demonstration of ZANU PF's recourse to tried and tested wartime tactics of political mobilization and control, as ZANLA Political Commissars operating in the countryside are credited for ensuring ZANU PF's strong victory in the 1980 independence election. ${ }^{80}$ But Political Commissars were more than just mobilizers of support in the 2013 election. They were also important surveillance tools, operating at the rural local level, with some of them even posing as ordinary farmers. ${ }^{81}$ The Political Commissars 'were living in the communities seeing what ideas and forces were shaping the communities thinking' and they acted as intelligence agents, conveying a wealth of information on local politics to MI, ${ }^{82}$ meaning that from $2008 \mathrm{MI}$ became

\footnotetext{
${ }^{74}$ Interview, Joice Mujuru, Beatrice, Zimbabwe, 4 January 2015.

${ }^{75}$ Interview, Key planner A in anti-Mujuru campaign, Harare, Zimbabwe, 15 December 2014. 'Red bricks' is a colloquial term for CIO, which has its roots in the fact that Chaminuka building (the official CIO headquarters) is built of red bricks.

${ }^{76}$ Interview, Military Officer A, Harare, Zimbabwe, 17 December 2014. Other military officers who shared this view are: Military Officer B, Harare, Zimbabwe, 23 December 2014; Military Officer C, Harare, Zimbabwe, 27 December 2013.

${ }^{77}$ Interview, Military Officer A, Harare, Zimbabwe, 17 December 2014; Interview, Military Officer B, Harare, Zimbabwe, 23 December 2014; Interview, Military Officer C, Harare, Zimbabwe, 27 December 2013; Interview, Military Officer D, Harare, Zimbabwe, 7 April 2014.

${ }^{78}$ Guardian, 'Why Robert Mugabe scored a landslide victory in Zimbabwean elections', 5 August 2013, <http://www.theguardian.com/world/2013/aug/05/robert-mugabe-zimbabwe-election-zanu-pf> (12 April 2015).

${ }^{79}$ Interview, Joice Mujuru, Beatrice, Zimbabwe, 4 January 2015; Interview, Military Officer B, Harare, Zimbabwe, 23 December 2014.

${ }^{80}$ Interview, Military Officer A, Harare, Zimbabwe, 17 December 2014; Interview, Military Officer B, Harare, Zimbabwe, 23 December 2014; Interview, Joice Mujuru, Beatrice, Zimbabwe, 4 January 2015.

${ }^{81}$ Ibid.

${ }^{82}$ Interview, Key planner A in anti-Mujuru campaign, Harare, Zimbabwe, 15 December 2014.
} 
increasingly involved in civilian or domestic intelligence gathering. This had traditionally been CIO’s sphere of activity.

Some of my interviewees spoke of MI as 'a shadow CIO', ${ }^{83}$ while others complained that it now wielded 'too much power'. ${ }^{84}$ Besides the surveillance reach Political Commissars afforded MI, the department did begin to rival CIO in some important respects from 2009. According to a senior figure in the security establishment:

\begin{abstract}
Military Intelligence traditionally reported to Number 1 [Mugabe] through CIO but because.... of these factions that are fighting... [MI] stopped sending...its reports through CIO. ... [MI] began to circumvent $\mathrm{CIO}$ and reported directly to Number 1 . Military Intelligence made technical changes. They imported special poisons from Kazakhstan, which work on you over 2 or 3 years so that it looks like some other disease. Military Intelligence imported state of the art digital equipment to monitor phones. Military Intelligence... now has a parallel phone monitoring system to CIO. I stopped talking anything of substance on the phone a long time ago. We kept asking Mutasa where this information that Joice was trying to kill Number 1 was coming from. Mutasa would say he has asked.... [CIO] many times and... there is no such information. It has not passed through my desk. Mutasa was puzzled because each time he went to see Number 1, Number 1 had intelligence reports Mutasa could not account for. This was Military Intelligence at work. They were bypassing CIO. ${ }^{85}$
\end{abstract}

In contrast, interviewees unaligned with the Mujuru faction claimed that CIO briefed Mugabe against the Mnangagwa faction. They alleged that in 2014 CIO produced dossiers that attempted to implicate Mnangagwa in various plots to undermine Mugabe's authority and demonstrated his unbridled ambition for political power. ${ }^{86}$

As shown in this section, shifting internal fissures, suspicions and politicization across time have beset CIO, Zimbabwe's principal intelligence institution. Thus, the steady rupturing of CIO's relationship with an increasingly powerful and independent MI after 2008 is closely linked to this institutional history of division and partisanship.

\title{
Gendered high-tech surveillance and assassination plots
}

In 2014 MI built a case that the Mujuru faction was plotting to assassinate Mugabe and conveyed this intelligence to the Zimbabwean president. ${ }^{87}$ According to Rugare Gumbo (former ZANU PF spokesman and Mujuru faction member) Mugabe claimed, in a ZANU PF politburo meeting, that 'we even have a recording of you [Rugare Gumbo] saying that if Mugabe is not careful we will do to him what the Congolese did to [president] Laurent Kabila' ${ }^{88}$ Gumbo denied making the utterances Mugabe mentioned, adding that 'intelligence [CIO] told me an underground military structure used voice cloning machines to make fake recordings of me

\footnotetext{
83 Ibid.

${ }^{84}$ Interview, Military Officer A, Harare, Zimbabwe, 17 December 2014.

85 Ibid.

${ }^{86}$ Interview, Intelligence Operative A, Harare, Zimbabwe, 9 January 2015; Interview, Key planner A in antiMujuru campaign, Harare, Zimbabwe, 15 December 2014.

${ }^{87}$ Interview, Military Officer A, Harare, Zimbabwe, 17 December 2014.

${ }^{88}$ Interview, Rugare Gumbo, Harare, Zimbabwe, 3 January 2015. Kabila was assassinated by one of his bodyguards in 2001.
} 
saying things I never said'. ${ }^{89}$ In Mujuru's case, she asserted that 'some people in intelligence went to ask on my behalf about the recording in which I am said to have been planning to kill Mugabe. They came back to me and said they had been told the video got burnt when ZTV [state-controlled TV broadcaster] was trying to play it for the nation'. ${ }^{90}$

State accusations of plots to assassinate Mugabe were not unprecedented and they have invariably targeted the Zimbabwean president's political rivals. Opposition party leaders such as Muzorewa, Ndabaningi Sithole and Tsvangirai were each charged with plotting to assassinate Mugabe in 1980, 1997 and 2002 respectively. The charges against Tsvangirai were the most notorious. They involved a former Israeli intelligence operative called Ari Ben Menashe who claimed that Tsvangirai requested that he assassinate Mugabe. ${ }^{91}$ The matter went to trial in 2004. A surveillance video of Tsvangirai's meetings with Menashe, in which it was alleged the assassination request was made, were part of the prosecution's vacuous case. Tsvangirai was duly acquitted of the assassination charge but the bogus trial had taken a toll on him: it distracted him from focusing on his political contest with Mugabe, it drained the MDC financially, ${ }^{92}$ and it exposed a degree of naivety on Tsvangirai's part for having been easily set up by Menashe and Zimbabwean intelligence. The assassination accusation against the Mujuru faction in 2014 was therefore only the latest in a sequence of similar political uses of alleged assassination plots against Mugabe’s rivals going back to 1980 .

Turning to the witchcraft accusation against Mujuru, a key actor in the campaign against her described surveillance footage of Mujuru's purported witchery as follows:

\begin{abstract}
In one of them [recordings] traditional healers are dancing around a pot on a fire. There was meat in the pot and when they were finished with their rituals she was supposed to start eating that meat with them and as they eat the meat the victim [Mugabe] starts dying. We also have her squeezing... juices from her ....[private parts].... Her juices were going to be used in a concoction to help her get [political] power. After the ritual, whoever she had sex with would become loyal to her. The ultimate form of recruitment for her was to have sex with the people she wanted in her faction. All these men who are in her faction who were supporting her like there is no tomorrow, she took them to bed. And this is why Mai Mujuru did not put up a fight when we started destroying her. She knew we had intelligence and if she put up a fight we would show Zimbabwe everything and she would be finished off completely. ${ }^{93}$
\end{abstract}

During ZANU PF’s December 2014 congress Mugabe publicly accused Mujuru of consulting traditional healers to gain political power. ${ }^{94}$ Mugabe claimed that 'one of the traditional healers said [to Mujuru] look for two tadpoles of different colours. One should be named Mugabe and the other should be called Mujuru and put them in water.... They were made to fight and if Mugabe's tadpole died then she would rule'. ${ }^{95}$ Mugabe repeated this witchcraft allegation against Mujuru

\footnotetext{
89 Ibid.

${ }^{90}$ Interview, Joice Mujuru, Beatrice, Zimbabwe, 4 January 2015.

${ }^{91}$ Guardian, 'Zimbabwe plot video “a smear”', 14 February 2002,

<http://www.theguardian.com/world/2002/feb/14/zimbabwe.andrewmeldrum> (17 April 2015).

92 Tsvangirai, Morgan Tsvangirai at the deep end.

93 Interview, Key planner A in anti-Mujuru campaign, Harare, Zimbabwe, 15 December 2014.

${ }^{94}$ The Herald, 'President on assassination: Mujuru engaged MDC-T, nangas', 4 December 2014,

$<$ http://www.herald.co.zw/president-on-assassination•-mujuru-engaged-mdc-t-nangas-•-vp-misses-third-straightindaba/> (16 April 2015).

95 Southern Times, 'Mujuru tried juju on me', 4 December 2014,

<http://www.southerneye.co.zw/2014/12/04/mujuru-tried-juju-mugabe/> (16 April 2015).
} 
on a different occasion, this time remarking that Mujuru engaged Nigerian wizards who asked her to slaughter hens by clipping their heads off: 'one [hen] was named after me, another my wife [Grace Mugabe].... it was said once Mujuru chopped their heads we would die... some of the things she did undressed from the top with her breasts exposed'. ${ }^{96}$ In response, Mujuru accused Mugabe of making 'fantastical and sexually lewd allegations' and also commented that Mugabe's claims she plotted to assassinate him had 'now been reduced to allegations of witchcraft, whose versions change on a daily basis'. ${ }^{97}$

During my interviews with intelligence operatives I requested to view the surveillance footage of Mujuru carrying out witchcraft acts. My requests were declined. To date the state has not made public any of this surveillance material showing Mujuru carrying out witchcraft acts. Rather than attempting to ascertain the 'truth' of these claims, it is more important to ask why Mugabe would publicly make use of unsubstantiated surveillance material about Mujuru's alleged witchery. And why would salacious imagery comprise a core component of these allegations? The answer partly lies in how witch-hunts are an effective, time honoured means of vanquishing political rivals, as noted above. Accusing Mujuru of witchery was an attempt to legitimize her proscription from ZANU PF's leadership. For example, on 26 November 2014, at the height of Mugabe's antiMujuru campaign, Mujuru avoided the final ZANU PF politburo meeting before commencement of the party's congress on 2 December. According to Mujuru she stayed away from this politburo gathering because:

\footnotetext{
someone in security tipped me off that youth had been organized to ambush me on my way to politburo and beat me up so I decided not to attend politburo. The youth were hiding in Queen Elizabeth School, which I pass on the way to the party headquarters and they would suddenly ambush my car and beat me. I was told the youth were in the hundreds and would then go to sing at the party headquarters and Mugabe would address them like he did the previous time. ${ }^{98}$
}

This episode indicates that Mujuru did become fair game for internal violence and her construction as a witch partly contributed towards making this possible. The preceding occasion Mujuru refers to in the quotation above was a large raucous demonstration outside the ZANU PF headquarters on 30 October 2014, with placards such as 'muroyi weku Dotito' (the witch from Dotito) and chants such as 'zimuroyi zimbuya repa Dotito' (the old woman from Dotito is a witch). Mugabe addressed the demonstrators favourably, thereby endorsing constructions of Mujuru as an enchantress. ${ }^{99}$

The second explanation is borne out in Koskela's observation that carrying out surveillance with technology is never purely technical: the 'presuppositions, experiences, emotions and attitudes'

\footnotetext{
96 Bulawayo 24, 'Bare breasted Mujuru wanted to kill me’.

${ }^{97}$ New Zimbabwe, 'Mujuru blasts Mugabe’s sexual fantasies, warns the president', 2 March 2015, <http://www.newzimbabwe.com/news-20939-Mujuru\%20slams\%20Mugabe’s\%20sexual\%20fantasies/news.aspx> (16 April 2015).

${ }^{98}$ Interview, Joice Mujuru, Beatrice, Zimbabwe, 4 January 2015.

${ }^{99}$ Dotito is Mujuru's rural home. Nehanda Radio, 'Demonstrations against VP Mujuru at ZANU PF headquarters', 30 October 2014, <http://nehandaradio.com/2014/10/30/demonstrations-vp-mujuru-zanu-pf-headquarters/> (16 April 2015).
} 
of operatives determine surveillance practices. ${ }^{100}$ Surveillance targets are gendered in terms of the nature of surveillance material that is gathered and what is emphasized about this information. Some of the alleged intelligence on Mujuru's activities clearly had lewd aspects. Thus some of Mujuru's political detractors in MI personified Koskela's 'peeping Tom goes high tech' because at times they focused on Mujuru's body and what she wore or did not wear. Indeed one senior military officer went as far as claiming that MI 'used drone cameras to build their case against Joice. They even recorded her naked in her bedroom'. ${ }^{101}$ It is worth highlighting that some of my interviewees described this purported surveillance material to me with a degree of enthrallment. Their descriptions were interwoven with explicit accounts about surveillance proof of Mujuru's alleged sexual encounters with male members of her faction, which, it is said, she engaged in to guarantee their loyalty. Claims that Mujuru used sex to ensure political loyalty are at worst misogynistic, implying that women cannot advance themselves without employing their bodies and sexuality; or at best highly gendered and patriarchal implying that there is something perverse or immoral about female sexuality. Ultimately the gendered nature of surveillance fortifies a patriarchal national politics in which women can be degraded and ostracized through sexualized accounts and claims of occult influence.

However, when writing about gender, politics and surveillance we must be wary of reproducing 'gender as a binary system' that depicts women as passive actors or even simply as victims; 'whenever you find a gendered practice, there is apt to be another element which turns the presumed gender relations upside down'. ${ }^{102}$ Some female politicians have invoked gendered discourses to their own benefit. For example, Grace Mugabe repeated many of the sexualized slurs against Mujuru:

\footnotetext{
I set up Mujuru and I now have a recording of her in a mini-skirt, speaking ill of me and the president. ...she was recorded while she was wearing a mini-skirt. I do not know whether she wanted to lure this person [who she was in conversation with] or not because the way she was dressed, it is embarrassing for a person of her stature. Do you know what she was saying in that video? She was saying 'why is Grace not telling her husband to step down?' ${ }^{103}$
}

Grace Mugabe sought to exert moral authority over Mujuru. She questioned Mujuru's moral decency and her suitability as a political leader. These gendered dimensions of politics are neither new nor unusual; what is interesting in this case is how they were made possible (or at least believable) by electronic surveillance data and the central role of the intelligence services in domestic politics.

\section{Conclusion}

\footnotetext{
${ }^{100}$ Hille Koskela, “'You should not wear that body”. The problematic of surveillance and gender', in Kirstie Ball, Kevin Haggerty and David Lyon (eds), Routledge handbook in surveillance studies (Routledge, London, 2014), p. 51.

${ }^{101}$ Interview, Military Officer A, Harare, Zimbabwe, 17 December 2014.

102 Koskela, “"You should not wear that body”, p. 55.

${ }^{103}$ Zimbabwe Mail, 'End beckons for Mujuru', 18 November 2014,

<http://www.thezimmail.co.zw/2014/11/18/end-beckons-for-mujuru/> (16 April 2015).
} 
In the cases discussed here, 'invisible' or seemingly 'non-existent' high-tech surveillance, taking the form of electronic bugs, hidden cameras, phone monitoring technology, voice cloning software and drone cameras (as one interviewee alleged) were apparently central to MI's surveillance strategies. MI's use of these new surveillance technologies highlights the enduring potential capacity and ambition of the Zimbabwean intelligence sector to, at the very least, deploy these technologies despite wider institutional problems in the context of economic decline and poor remuneration for state employees, politicization, militarization and internal divisions.

Mugabe was persuaded by MI to expunge the Mujuru faction because it posed a greater threat to his hold on power than the Mnangagwa group. Before Mugabe’s crackdown, the Mujuru faction controlled all the influential posts in ZANU PF, such as the deputy presidency, secretary general, national chairman, commissariat, party spokesperson and the youth league leadership. ${ }^{104}$ The Mujuru faction also dominated the cabinet and had made substantial inroads towards controlling part of the intelligence sector, as shown here. Crucially, the Mujuru faction directed nine out of a possible ten ZANU PF provincial leaderships, which elected national party leaders. Therefore, if Mugabe had not expunged the Mujuru faction from provincial leadership positions before the December 2014 elective congress and Mujuru challenged him for the presidency at the party assembly, Mugabe would have faced certain defeat and an ignominious exit from power.

In addition to the pivotal role MI played in Mugabe's resolution to purge the Mujuru group in 2014, the Zimbabwean president was given some incentive by the fact that he held General Mujuru responsible for his loss in the March 2008 poll. In a sense, Mujuru paid a political penalty for General Mujuru’s machinations to remove Mugabe from power. General Mujuru (nom de guerre: Rex Nhongo) left a complicated legacy within ZANU PF. As Nhongo he was a valiant hero of the liberation war, a symbol of ZANLA at the height of its insurgent pursuits, and he helped the Commonwealth Monitoring Force to manage the delicate 1979-80 ceasefire. No ZANLA guerrilla leader championed Mugabe's rise to the leadership of ZANU PF in the 1970s more than Nhongo. ${ }^{105}$ As General Mujuru he oversaw the integration of the Zimbabwe National Army in the independence period. But from the mid-1980s, General Mujuru was increasingly critical of Mugabe's policies, such as his costly decision to deploy the army in the Democratic Republic of the Congo on the side of Kabila in the Second Congo war (1998-2003). ${ }^{106}$ General Mujuru was also one of the pivots of succession politics in ZANU PF, even to the point of playing a role in 'the Makoni issue', which Mugabe saw as having caused his defeat in the March 2008 election. As a result, General Mujuru's chequered and divisive legacy undercut Mujuru and her faction's standing in Mugabe's eyes. ${ }^{107}$

This article contributes towards understanding the political role of Zimbabwe's intelligence establishment. The MI leadership supported Mnangagwa in the succession war. MI provided or fabricated surveillance on Mujuru, constructing a gendered case aimed at destroying her presidential ambition. A divided CIO attempted to ensure Mujuru succeeded Mugabe by compiling intelligence that cast the Mnangagwa faction in adverse light. Ultimately, Mugabe was

\footnotetext{
${ }^{104}$ Interview, Key planner A in anti-Mujuru campaign, Harare, Zimbabwe, 15 December 2014; Interview, Key planner B in anti-Mujuru campaign, Harare, Zimbabwe, 8 January 2015.

105 Tendi, 'Ideology, civilian authority'; Wilfred Mhanda, Dzino: memories of a freedom fighter (Weaver Press, Harare, 2011).

${ }^{106}$ Interview, Military Officer A, Harare, Zimbabwe, 17 December 2014; Interview, Military Officer B, Harare, Zimbabwe, 23 December 2014.

${ }^{107}$ Interview, Joice Mujuru, Beatrice, Zimbabwe, 4 January 2015.
} 
persuaded by MI to expel the Mujuru group from key posts in ZANU PF and the government, in a manner that revealed the degree to which the intelligence sector was permeated by gendered and patriarchal values and discourses. 